\title{
PELATIHAN KEWIRAUSAHAAN TENTANG BISNIS RUMAHAN BAGI IBU RUMAH TANGGA DI DESA RENGASDENGKLOK SELATAN KECAMATAN RENGASDENGKLOK KAB KARAWANG
}

\author{
Ayu Fitri, Budi Rismayadi, Mumun Maemunah \\ Universitas Buana Perjuangan karawang, Indonesia \\ ayufitri@ubpkarawang.ac.id
}

\begin{abstract}
The implementation of community service activities aims to increase knowledge about home business so as to improve community welfare. Community service methods used are lectures and discussions. The material covers about home-based businesses that generate millions of turnover. The results obtained from this activity, all participants stated that this activity was very useful to increase knowledge and insight on how to take advantage of every home-based business opportunity.
\end{abstract}

Keywords: entrepreneurship training, home business, housewives.

\begin{abstract}
Abstrak
Penyelenggaraan kegiatan pengabdian kepada masyarakat ini bertujuan meningkatkan pengetahuan tentang bisnis rumahan sehingga dapat meningkatkan kesejahteraan masyarakat. Metode pengabdian kepada masyarakat yang digunakan adalah ceramah dan diskusi. Materi mencakup tentang usaha rumahan yang menghasilkan omset jutaan. Hasil yang diperoleh dari kegiatan ini, seluruh peserta menyatakan kegiatan ini sangat bermanfaat dapat menambah pengetahuan dan wawasan bagaimana cara memanfaatkan setiap peluang usaha rumahan.

Kata Kunci: Pelatihan Kewirausahaan, Bisnis Rumahan, Ibu Rumah Tangga.
\end{abstract}

\section{Pendahuluan}

Kewirausahaan merupakan suatu istilah dari bahasa Inggris yaitu entrepreneurship dan bahasa Perancis entreprende yang memiliki arti pencipta, pertama kali atau pengelola usaha. Istilah pertama kali dicetuskan oleh Richard Cantillon (dalam Friences, 2010) untuk menyatakan gambaran dari pengusaha yang mampu meningkatkan produktivitas rendah ke level tinggi dan menghasilkan sutu produk lebih banyak setiap waktunya. Kewirausaahaan menurut Sanusi (2011), menyatakan "Suatu nilai yang tentunya diciptakan dalam suatu perilaku yang bisa dijadikan dasar dari sumber daya, tenaga penggerak, tujuan, siasat, kiat, proses, serta hasil bisnis". Jadi kewirausahaan merupakan kemampuan untuk menjadi kreatif dan inovatif dalam mengambil peluang menuju tujuan, yaitu sukses. Inti dari kewirahusahaan adalah untuk mencari sesuatu yang berbeda dan baru, guna membantu pemenuhan kebutuhan konsumen.

Menurut Suryana (2011) Kewirausahaan adalah suatu kemampuan untuk memberi nilai tambah suatu produk di pasaran, yang tentunya menggunakan beberapa cara. Sedangkan menurut Coulter (Friences, 2010) bahwa kewirausahaan dikaitkan dengan pembentukan bisnis baru yang menghasilkan keuntungan, nilai, dan produk baru atau jasa yang unik serta kreatif. Ropke (Friences, 2010) juga mengungkapkan bahwa kewirausahaan 
adalah proses menciptakan hal baru atau membuat sesuatu berbeda dari yang pernah ada sebelumnya. Kewirausahaan adalah kegiatan seseorang dalam melakukan aktivitas yang bersifat usaha, sedangkan wirausahawan merupakan pelaku/orang yang menjalankan aktivitas tersebut.

Menurut Zimmeer (dalam Saragih, 2017) kewirausahaan dibedakan menjadi empat golongan, yaitu:

1. Part Time Entrepreneur yakni suatu kelompok wirausaha yang melakukan kegiatan usaha pada sebagian waktunya saja atau hanya bersifat sampingan maupun hobi.

2. Home base New Ventures yakni suatu kelompok wirausaha dengan rintis usahanya didasarkan pada asal tempat tinggal (domisili).

3. Family yakni suatu kelompok wirausaha yang dilakukan secara turun temurun oleh anggota keluarganya.

4. Copreneur yakni sutau kelompok wirausaha yang didirikan oleh beberapa orang (dua orang atau lebih), sehingga terjadi kerjasama dalam menjalankan dan mengelola usaha yang merupakan milik bersama. Biasanya dilakukan pasangan suami dan istri.

Setelah mengetahui golongan wirausaha. Terdapat sepuluh kesalahan fatal; yang dilakukan usaha pemula yang dikemukakan oleh Thomas Zimmere, dkk (2008, 39-42) meliputi:

1. Ketidakmampuan Manajemen

Manajemen yang buruk dalam kebanyakan perusahaan kecil menjadi penyebab utama kegagalan bisnis. Manajer perusahaan kecil tidak memiliki kemampuan untuk menjalankannya dengan baik. Pemilik perusahaan kurang mempunyai kemampuan kepemimpian pertimbangan yang baik, dan pengetahuan yang diperlukan dalam menjalankan bisnis. Hal yang mematikan perusahaan biasanya bukanlah ketidakcukupan modal, bakat, atau informasi melainkan sesuatu yang lebih mendasar, yaitu kurangnya penilaian dan pemahaman yang baik.

2. Kurang Pengalaman

Seorang pengusaha perlu memiliki pengalaman dalam bidang yang ingin dimasukinya. Contoh: seorang yang ingin membuka bisnis fotocopy, maka orang tersebut harus bekerja di perusahaan distributor mesin fotocopy. Hal ini akan memberikan pengalamn praktis dan pengetahuan mengenai seluk-beluk bisnis tersebut, yang dapat menujukkan perbedaan antara kesuksesan dan kegagalan.

3. Pengendalian Keuangan yang Buruk

Manajemen yang sehat adalah kunci keberhasilan perusahaan kecil, dan manajer yang efektif menyadari bahwa semua keberhasilan bisnis memerlukan kendali keuangan yang layak. Keberhasilan bisnis juga memerlukan modal dalam jumlah ang cukup pada saat awalnya. Pemilik perusahaan kecil sering kali membuat kesalahan pada awal bisnis dengan hanya "bermodal dengkul" yang dapat menjadi kesalahan fatal.

4. Lemahnya Usaha Pemasaran

Seorang pengusaha harus membangun basis pelanggan yang terus berkembang dengan melakukan upaya pemasaran tanpa kenal Lelah dan kreatif. Seorang pengusaha yang kreatif menemukan cara untuk memasarkan bisnis secara efektif kepada pelanggan untuk mencapai target penjualan.

5. Kegagalan Mengembangkan Perencanaan Strategis 
Seorang pengusaha pada perusahaan kecil sering kali mengabaikan proses perencanaan strategis, karena dianggal hal tersebut hanya bermanfaat bagi perusahaan besar. Sebuah bisnis perusahaan tanpa stratei yang ditentukan dengan jelas maka akan memuat perusahaan tersebut tidak memiliki dasar yang berkesinambungan untuk meniptakan dan memelihara keunggulan bersaing di pasar. Pembangunan rencana strategis memaksa wirausahawan untuk menilai secara realistis potensi bisnis yang direncanakan. Apakah produk perusahaan memang diinginkan dan mampu dibeli pelanggan? Siapa pelanggan sasarannya? Bagaimana cara bisnis ini menarik dan mempertahankan pelanggan? Apa dasar perusahaan agar dapat melayani kebutuhan pelanggan dengan lebih baik disbanding perusahaan yang telah ada.

6. Pertumbuhan Perusahaan yang Tidak Terkendali

Pertumbuhan merupakan suatu yang alamiah, sehat dan didambakan oleh semua perusahaan, tetapi pertumbuhan haruslah terencana dan terkendali. Peter Drucker menyatakan bahwa perusahaan baru berdiri dapat diperkirakan mengalami pertumbuhan terlalu pesat dibandingkan dengan basis modal yang dimiliki apabila penjualan meningkatkan $40 \% \mathrm{~s} / \mathrm{d} 50 \%$. Perusahaan yang masih muda umurnya sebaliknya tidak terburu-buru untuk melakukan ekspansi, kerena keputusan ekspansi bisnis bagi perusahaan baru dapat menyebabkan kegagalan.

7. Lokasi yang Buruk

Pemilihan lokasi yang tepat, untuk bisnis apapupunmerupakan seni dan ilmu. Lokasi perusahaan sering kali dipilih tanpa penelitian, pengamatan, dan perencanaan yang layak. Seorang pengusaha pemula memilih lokasi terlalu riskan untuk dilakukan secara untung-untungan, khususnya untuk bisnis eceran, denyut jantung kehidupan bisnis yaitu penjualan sangat dipengaruhi oleh pemilihan lokasi.

8. Pengendalian Persediaan yang Tidak Tepat

Investasi terbesar yang dilakukan para pemilik usaha kecil adalah dalam persediaan, namun pengendalian persediaan adalah salah satu tanggung jawab manajerial yang paling dibaiakan . tingkat persediaan yang tidak mencukupi akan mengakibatkan kekurangan dan kehabisan stok, mengakibatkan pelanggan kecewa dan pergi. Fenomena yang sering terjadi adalah bahwa wirausahawan tidak hanya memiliki persediaan dalam jumlah berlebih, tetapi juga mempunyai terlalu banyak persediaan yang salah jenis.

9. Penetapan Harga yang Tidak Tepat

Penetapan harga yang akan menghasilkan laba berarti bahwa seorang pengusaha harus memahami besarnya biaya untuk membuat, memasarkan, serta mendistribusikan produk dab hasa perusahaan. Seorang pengusaha sering kali dengan mudah menetapkan harga berdasarkan ide yang samar-samar "menjual produk terbaik pada harga terendah". Seorang pengusaha biasanya menetapkan harga terlalu rendah atas produk yang dijual.

10. Ketidakmampuan Membuat "Transisi Kewirausahaan"

Keberhasilan melewati tahap awal kewirausahaan tidak menjamin kesuksesan perusahaan. Pertumbuhan perusaah setelah berdiri, biasanya memerlukan perubahan drastis gaya manajemen, satu hal yang tidak dapat dilakkan dengan baik oleh pada wirausahawan. 
Adapun ide bisnis rumahan yang menghasilkan omset jutaan rupiah dijelaskan lebih rinci sebagai berikut:

1. Bisnis Online

Salah satu bisnis yang sekarang tengah hits adalah online shop. Dalam hal ini, online shop adalah salah satu cara berjualan dengan memanfaatkan internet. Jika anda kesulitan masalah modeal untuk membuka sebuah usaha, coba saja bisnis ini. Mekanisme menjalankan online shop cukup simple. Apalagi sekarang banyak website took online atau marketplace yang lebih memudahkan penjual dan pembeli untuk melakukan transaksi. Hal ini juga memungkinkan anda membuat online shop tanpa modal.

Kiat sukses memulai bisnis online shop, lakukan hal-hal berikut:

a. Tentukan jenis produk yang akan dijual di online shop. Misalnya, online shop yang anda kelola khusus menjual produk fashion. Maka produk yang anda jual sekitaran fashion seperti baju, celana, sepatu, dan lain sebagainya, bukan dicampurkan dengan produk makanan atau rumah tangga.

b. Siapkan website khusus bagi produk, baik berbayar ataupun gratisan. Daftarkan took online kamu ke beberapa situs marketplace, seperti tokopedia, shopee, bukalapak, dan lain-lain. Jangan lupa membuat akun di sosial media seperti facebook dan instagram.

c. Carilah distributor atau pemasok yang resmi dan murah untuk memasok barangbarang ke took online anda. Anda cukup mengambil gambar produk kemudian promosikan melalui internet, baik media sosial maupun toko-toko online dengan mengambil keuntungan.

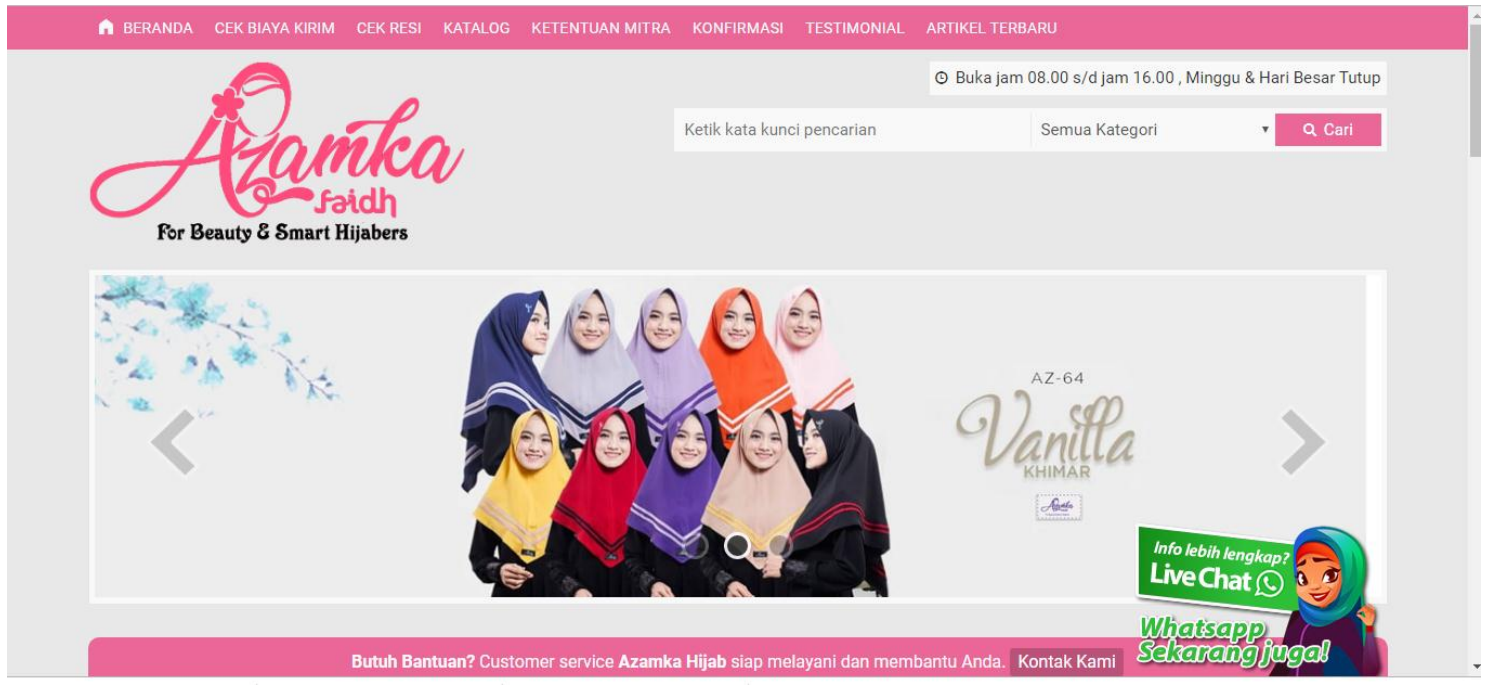

Gambar 1 Toko Online

Manajemen bisnis yang dapat dilakukan untuk menjamin kesuksesan usaha online shop antara lain:

a. Jagalah kualitas barang. Kirim produk distributor resmi dan terpercaya dan pastikan produk yang anda jual memiliki kualitas baik.

b. Berikan penjelasan yang detail tentang kelebihan dan kekurangan produk. Anda harus bisa memilih produk yang tepat bagi konsumen yang masih bingung. Sebab, beberapa 
konsumen akan menanyakan pendapatt anda mengenai produk yang tepat baginya. Pastikan anda memberikan pilihan yang tepat. Jika konsumen tersebut cocok dengan produk yang anda tawarkan, kemungkinan besar ia akan memesan lagi. Bahkan, boleh jadi ia akan membeli sambil membawa konsumen lain.

c. Berikan diskon. Tetapkan sistem potongan harga atau diskon untuk pembelian jumlah tertentu. Harus diingat bahwa mengambil sedikiti keuntungan tapi laris lebih baik daripada meraih keuntungan besar tetapi hanya sekali.

d. Bersikap ramah kepada konsumen. Jangan segan-segan memberikan saran kepada konsumen berkaitan dengan produk yang dibeli. Anda juga bisa membuka konsultasi online dalam website atau media sosial. Cantumkan kemudahan dalam melakukan transaksi hingga pengiriman barang. Oleh karena itu, kita juga harus bekerja sama dengan jasa pengiriman barang setempat.

2. Bisnis Kuliner

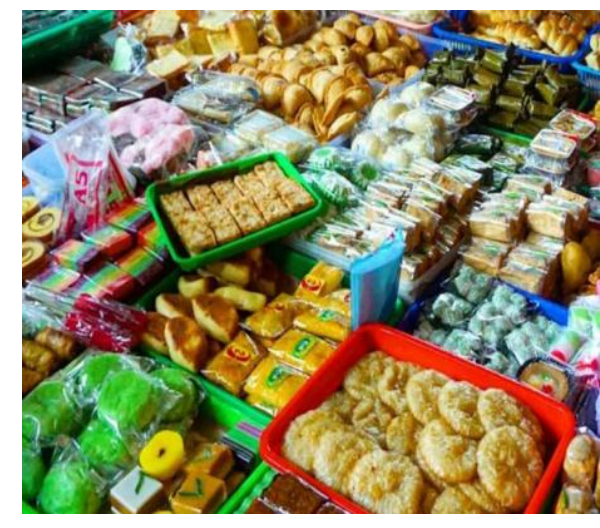

Salah satu contoh ide bisnis dari bisnis kuliner yakni jajanan pasar. Jajanan pasar masih sangat diminati oleh pasar. Hal ini terbukti dengan semakin banyaknya penjual jajanan pasar yang ada di pinggir-pinggir jalan, terutama jalan raya utama atau protocol. Penikmat jajanan pasar ini juga beragam, mulai dari anak-anak, remaja, hingga orang tua. Mereka menyukai jajanan pasar dikarenakan rasanya yang khas dan tidak dapat tergantikan dengan kudapan moder sejenis bakery atau cake. Maka, tak heran bila bisnis jajanan pasar masih berpeluang untuk dijalankan.

Untuk memulai bisnis produksi jajanan pasar. Hal yang perlu diperhatikan sebagai berikut:

a. Menguasai keterampilan membuat aneka macam jajanan pasar yang lezat dan rasanya khas.

b. Memiliki jaringan pemasaran uang luas meliputi toko-toko penjual jajanan pasar dan para penjual jajanan pasar keliling.

c. Memproduksi hanya jajanan pasar yang laris dipasaran sehingga kemungkinan laku lebih besar.

d. Memasang harga jajanan pasar lebih rendah daripada yang ditawarkan para pesaing. Manajemen bisnis yang dapat dilakukan untuk menjamin kesuksesan usaha jajanan pasar antara lain:

a. Senantiasa memasang harga jajanan prendah daripada yang ditawarkan oleh pesaing.

b. Senantiasa menjaga kelezatan dan kekhasan rasa jajanan pasar agar tidak seperti cemilan/kudapan modern yang banyak dijumpai di minimarket ataupun supermarket.

c. Memberikan bonus khusus bagi jaringan pemasar yang bisa menjual jajanan pasar melebihi targhet setiap harinya.

d. Memasarkan jajanan pasar di minimarket dan supermarket apabila sudah cukup berkembang agar target konsumen yang dicapai bisa semakin luas. 
3. Bisnis Jasa

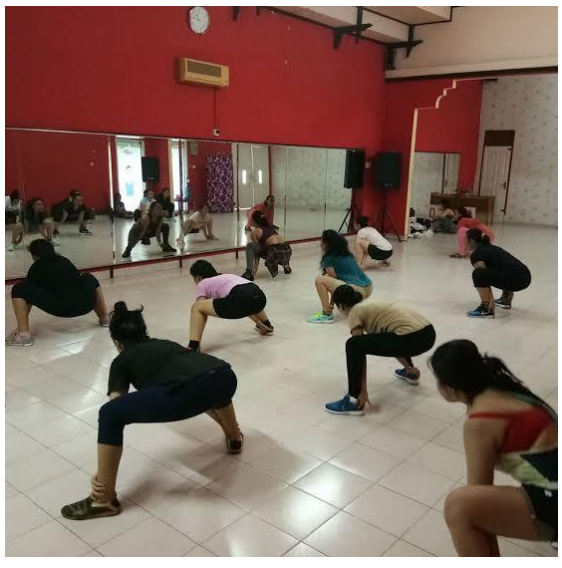

Salah satu contoh dari bisnis jasa yang dapat dilaksanakan di rumah yakni sanggar senam. Sasaran utama bisnis sanggar senam adalah ibu-ibu rumah tangga dan wanita muda. Meskipun segmennya cukup terbatas, binis ini tak pernah surut. Hal ini disebabkan semakin hari kian banyak para wanita ingin tampil seksi dan sehat. Apabila memiliki ruangan yang cukup luas di rumah, tidak ada salahnya mencoba menjalankan bisnis ini.

Kiat sukses memulai bisnis sanggar senam antara lain:

a. Mencari instruktur senam yang berpengalaman dan yang lebih penting lagi, bertubuh seksi dan sehat. Tujuannya adalah menarik minat serta semangat ibu-ibu rumah tangga dan wanita muda untuk mengikuti semangat.

b. Merenovasi ruangan agar benar-benar terlihat seperti ruangan khusus senam yang di dindingnya memiliki cermin.

c. Menyediakan matras, barbel kecil, lemari kecil/loker, tempat minum, serta peralatan lain yang diperlukan untuk kebutuhan ibu-ibu rumah tangga serta wanita muda yang mengikuti senam.

Manajemen bisnis yang dapat dilakukan untuk menjamin kesuksesan usaha sanggar senam, diantaranya sebagai berikut:

a. Memakai jasa instruktur pengalaman, bertubuh seksi dan sehat, serta mudah akrab dengan ibu-ibu rumah tangga dan wanita muda yang mengikuti senam.

b. Memberlakukan system membership, yakni system keanggotaan dengan biaya yang lebih rendah dibandingkan biaya senam harian.

c. Menyediakan ruangan senam yang nyaman serta memiliki musik-musik senam yang modern alias tidak ketinggalan zaman.

d. Gencar melakukan promosi lewat brosur-brosur yang disebarkan kepada ibu-ibu rumah tangga dan wnaita muda sebagai sasaran utama.

\section{Bisnis Fashion}

Salah satu ide bisnis fashion yang dapat dilaksanakan di rumah yakni jualan hijab. Hijab atau penutup aurat bagian kepala perempuan semakin ramai diperbincangkan dan bahkan menjadi tren. Imbasnya, mulai dari perempuan muda hingga ibu-ibu muslim lebih suka mengenakan hijab setiap kali pergi keluar rumah. Bisnis ini menyimpan prospek menjanjikan yang tentunya menghasilkan keuntungan cukup besar. 


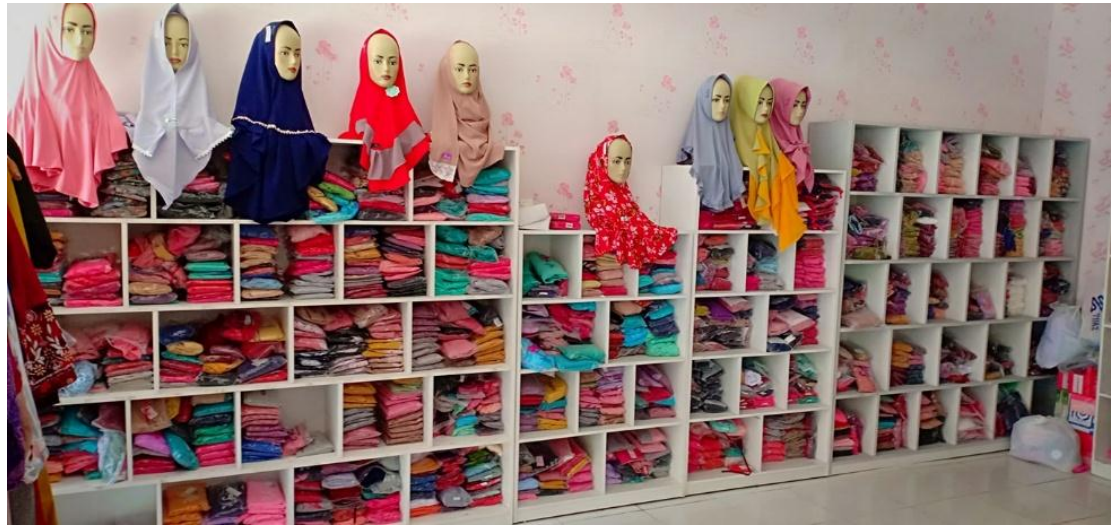

Gambar 3 Lemari Stok Hijab

Kiat sukses memulai bisnis hijab antara lain:

a. Menentukan lokasi yang diperkirakan strategis dan ramai mobilitas. Namun bisnis hijab dapat dilakukan di rumah pula.

b. Mencari pemasok yang menjual aneka macam hijab degan kualitas terbaik dan harga terjangkau.

c. Mengikuti perkembangan hijab agar anda mengetahui jenis dan model yang sedang digemari dan banyak dicari.

d. Menjual jenis-jenis dan model-model hijab, mulai dari anak-anak, remaja, hingga ibuibu/wanita dewasa.

Manajemen bisnis yang dapat dilakukan untuk menjamin kesuksesan bisnis hijab, diantaranya sebagai berikut:

a. Menwarkan hijab secara kompetitif, tetapi tidak lebih tinggi daripada yang ditawarkan pesaing.

b. Menjual koleksi kerudung yang lengkap, mulai dari bahan, motif/corak, dan modelnya. Hal ini penting agar toko anda bisa dijadikan rujukan bagi banyak orang yang membeli hijab.

c. Senantiasa menghadirkan hijab-hijab terbaru yang sedang tren dan banyak diminati pasar.

5. Bisnis Kerajinan Tangan

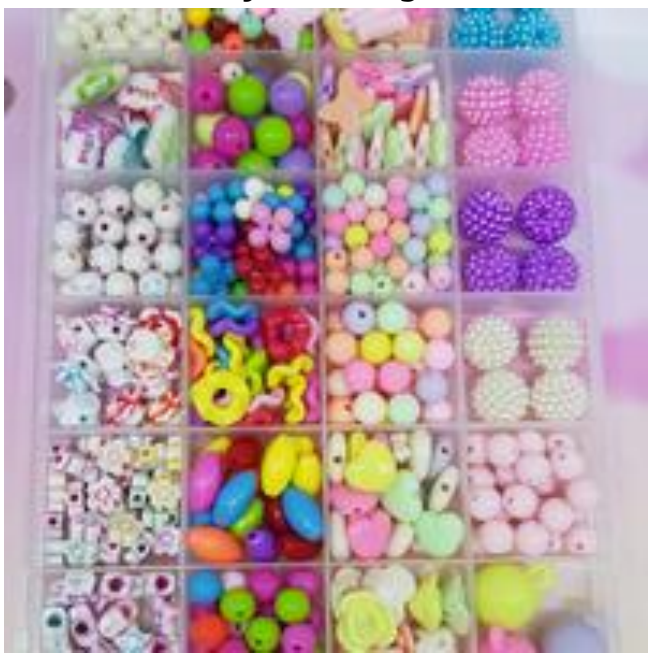

Salah satu contoh dari bisnis kerajinan tangan yang dapat dilaksanakan di rumah yakni kreasi manik-manik. Kreasi manik-manik merupakan sebuah bisnis kerajinan tangan (handmade) dengan bahan manik-manik yang diolah menjadi sebuah produk seperti aksesoris, souveis, ataupun hiasan. Pasar terbesar aksesoris manik-manik adalah perempuan dewasa dan mahasiswi. Dalam menjalankan bisnis ini, anda memerlukan kreativitas untuk membuat desain menarik. Jangan lupa sesuaikan kreasi manikmanik dengan tren yang ada di masyarakat. Adna bisa mencari inspirasi desain aksesoris, baik dari 
majalah maupun internet. Kegiatan merangkai manik-manik ini tentu bisa digunakan untuk mengisi waktu luang sekaligu menghasilkan pundi-pundi uang.

Kiat sukses untuk menjual produk manik-manik antara lain:

a. Lakukan riset terlebih dahulu. Sebelum merangkai manik-manik menjadi sebuah produk, lakukan riset pasar untuk mengetahui tren aksesoris apapun yang sedang hits di pasaran. Misanya: bros atau korsase untuk hijab, kalung, gelang atau gantungan kunci.

b. Memperluas jangkau pasar. Supaya menghaislkan omzet lebih besar, anda memperluas jangkauan pemasaran. Selain mempromosikan melalui edia sosial, anda bisa bekerjasama dengan beberapa toko, swalayan, butik, ataupun toko aksesoris untuk ikut menjual produk manik-manik buatanmu, tentunya dengan fee yang sudah disepakati. Pastikan memperluas jangkauan pasar dengan menjual secara online melalui marketplace-marketplace yang sudah banyak tersedia di internet.

Meningkatkan produksi. Bila bisnis manik-manik anda sudah stabil, taka da salahnya memulai menerima pemesanan dan memproduksi dalam jumlah besar. Dengan demikian, anda bukan hanya membidik konsumen akhir, tetapi juga mampu menjaring para agen atau reseller yang menjual kembali kepada pelanggan mereka.

\section{Metode}

Sasaran kegiatan ini adalah ibu rumah tangga di Kecamatan Rengasdengklok. Pemilihan dan penetapan sasaran pelatihan ini berdasarkan pertimbangan bahwa ibu rumah tangga setelah selesai pekerjaan rumah menghabiskan waktu dengan menonton televisi, ngerumpi bersama tetangga, dan banyak halnya. Kegiatan pelatihan ini diharapkan mengisi waktu luang ibu rumah tangga dengan kegiatan yang menghasilkan income tambahan bagi keluarganya, serta bisa dilaksanakan di rumah.

Langkah-langkah Kegiatan PPM

Berikut merupakan langkah-langkah yang dilakukan dalam kegiatan pelatihan ini:

1. Tahap Persiapan

Tahap persiapan yang dilakukan meliputi:

a. Survey

Tahap ini merupakan tahap paling awal yang dilakukan, tim pelaksana mengunjungi tempat sasaran dan berdialog langsung dengan warga, ataupun pemerintah desa setempat. Hal ini penting dilakukan untuk mengetahui dan memahami kondisi daerah yang akan dijadikan sasaran kegiatan dan juga sebagai pendekatan tim terhadap warga.

b. Pemantapan dan penentuan lokasi dan sasaran

Tahap ini dilakukan dengan cara berkunjung kembali ke tempat sasaran guna menyampaikan dan mensosialisasikan rencana kegiatan yang akan dilakukan serta melakukan pendaftaran terhadap peserta yang akan mengikuti pelatihan.

c. Penyusunan bahan/materi

Tahap ini meliputi penyusunan modul dan presentasi power point yang akan disampaikan.

d. Persiapan peralatan dan alat peraga 
Tahap ini memastikan bahwa peralatan pendukung seperti LCD, spidol, white board dan juga peralatan paraga untuk keperlukan praktek seperti handphone sebagai media berbisnis online, jajanan pasar sebagai contoh bisnis kuliner, hijab sebagai media bisnis fashion, musik erobik sebagai media berbisnis jasa, manikmanik sebagai media pembuatan kerajinan.

2. Tahap Pelaksanaan Pelatihan

Tahap pelaksanaan pelatihan dibagi menjadi tiga sesi, yakni:

a. Sesi Pertama : Penayangan Video Wirausaha Sukses dengan Bisnis di Rumah dengan target agar ibu-ibu bersemangat memanfaatkan waktu yang dimiliki untuk menjadi wirausahawan.

b. Sesi Kedua : Pemaparan materi tentang "Kewirausahaan serta Kesalahan Fatal Pengusaha Pemula".

c. Sesi Ketiga: Kiat Sukses menjalankan Bisnis Rumahan yang menghasilkan omset jutaan rupiah.

3. Metode yang digunakan terdiri dari beberapa metode:

a. Metode Ceramah

Metode ceramah adalah metode pembelajaran berupa penyampaian paparan materi dari instruktur/trainer dan peserta sebagai pendengarnya.

b. Metode Tanya jawab

Metode tanya jawab sangat penting bagi para peserta pelatihan, baik disaat menerima penjelasan materi ataupun saat sesi praktek. Metode ini memungkinkan peserta menggali pengetahuan sebanyak-banyaknya tentang hal-hal lain yang berhubungan dengan palatihan tetapi tidak tersampaikan oleh tim dosen. Pertanyaan juga bias diajukan dari tim dosen kepada para peserta sebagai bentuk evaluasi terhadap tingkat pemahaman peserta.

\section{Hasil dan Pembahasan}

Kegiatan pelatihan kewirausahaan tentang bisnis rumahan Desa Rengasdengklok Selatan Kecamatan Rengasdengklok Kabupaten Karawang dilaksanakan pada Minggu, 03 Maret 2019. Kegiatan pelatihan ini berjalan dengan lancar dan baik yang diikuti oleh para peserta dari kalangan ibu rumah tangga. Kesan dari peserta, kegiatan ini sangat bermanfaat bagi ibu-ibu. Mereka dapat memanfaatkan waktu luang dengan kegiatan yang dapat menghasilkan uang dan dikerjakan di rumah. Jadi pekerjaan rumah ke urus, keluarga tidak terlantar, uang bertambah.

Hasil tersebut di atas menunjukkan bahwa pelatihan kewirausahaan tentang bisnis rumahan Desa Rengasdengklok Selatan Kecamatan Rengasdengklok dapat meningkatkan kesejahteraan dan keterampilan ibu rumah tangga, sehingga dapat meningkatkan perekonomian.

\section{Kesimpulan}

Kegiatan pelatihan ini dapat diselenggarakan dengan baik dan berjalan lancar sesuai dengan rencana kegiatan yang telah disusun meskipun belum semua peserta menguasai materi dalam melakukan kewirausahaan secara baik dan materi yang disampaikan. Kegiatan ini mendapat sambutan yang positif dan terlihat dari aktifnya 
peserta dalam mengikuti semua materi yang disampaikan dan terlihat dari antusiasnya pertanyaan yang ditanyakan ketika kegiatan dilakukan. Adanya kegiatan lanjutan yang berupa pelatihan sejenis yang diselanggarkan secara periodik, sehingga dapat meningkatkan perekonomian.

\section{Daftar Pustaka}

Damaya. (2018). Super Student Preneur. Yogyakarta: Laksana

Frinces, Z.H. (2010). Pentingnya Profesi Wirausaha Indonesia. di Indonesia. Jurnal Ekonomi dan Pendidikan, 7(1), h/m 34-57

Puspito, H. (2017). Bisnis dari Rumah Penghasilan Jutaan Rupiah. Jakarta: Ednovate Publishing

Sanusi, A. (2011). Metodologi Penelitian Bisnis. Jakarta: Salemba Empat

Saragih, R. (2017). Membangun Usaha Kreatif, Inovatif, dan Bermanfaat melalui Penerapan Kewirausahaan Sosial. Jurnal Kewirausahaan, 3 (2), hlm 26-34.

Suryana Y., Bayu K. (2011). Kewirausahaa: Pendekatan Karakteristik Wirausahawan Sukses. Jakarta: Kencana

Zimmerer, Thomas W., Scarborough, Norman M., dan Wilson, Doug. (2008). Kewirausahaan dan Manajemen Usaha Kecil. Edisi 5 Buku I. Terjemahan: Deny Arnos Kwary dan Dewi Fitriasari. Jakarta: Salemba Empat. 